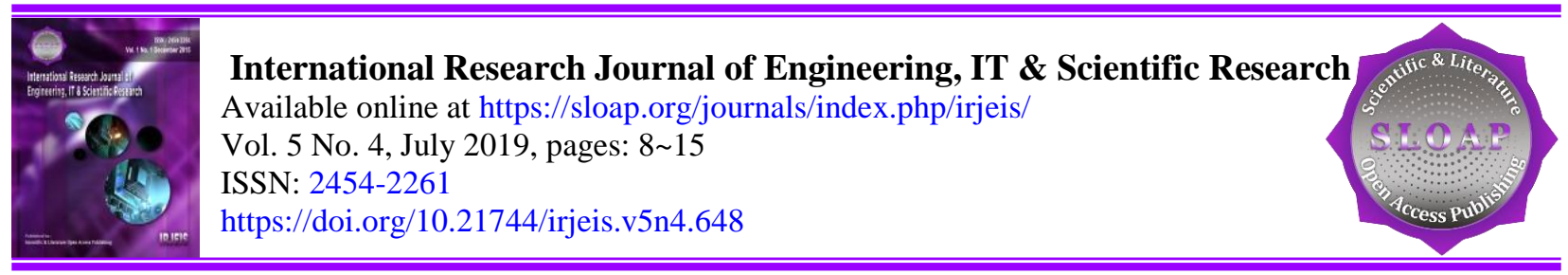

\title{
Application of RULA Analysis on Work Posture Improvement to Reduce Workers' Fatigue and Musculoskeletal Complaints and to Accelerate Processing Time of Wok Molding
}

\begin{tabular}{|c|c|}
\hline & $\begin{array}{r}\text { Tri Budiyanto }^{a} \\
\text { Nyoman Adiputra }^{\mathrm{b}} \\
\text { I Dewa Putu Sutjana }^{\mathrm{c}} \\
\text { Ketut Tirtayasa }^{\mathrm{d}}\end{array}$ \\
\hline Article history: & Abstract \\
\hline $\begin{array}{l}\text { Received: } 27 \text { March } 2019 \\
\text { Accepted: } 31 \text { May } 2019 \\
\text { Published: } 7 \text { June } 2019\end{array}$ & $\begin{array}{l}\text { The aim of the research was to analyze the work posture of the workers using } \\
\text { the RULA method. The research was conducted experimentally by applying } \\
\text { the treatment by subject design using } 12 \text { samples which were given two } \\
\text { treatments; wok molding workers with the former molding facility (P0), and } \\
\text { wok molding workers with the new molding facility with the ergonomic } \\
\text { intervention (PI). Conclusion of this research is the RULA analysis result on }\end{array}$ \\
\hline $\begin{array}{l}\text { Keywords: } \\
\text { RULA; } \\
\text { wok molding; } \\
\text { work facility; } \\
\text { work posture; } \\
\text { worker; }\end{array}$ & $\begin{array}{l}\text { the work posture of placing the end work on the temporary place }(\mathrm{PO}) \text { gave a } \\
\text { score of } 7 \text {. This score shows a high-risk level and needs work posture } \\
\text { improvement immediately. The work on PI showed the RULA score of } 3 \text {, } \\
\text { which means that there is a decrease from a high risk at a low-risk level. The } \\
\text { average time needed to mold a wok on P0 was } 1.46 \text { minutes/unit, and on PI } \\
\text { was } 1.23 \text { minutes/unit or down } 18.7 \% \text {. Therefore it recommended for wok } \\
\text { molding worker to use ergonomic work posture (PI). }\end{array}$ \\
\hline
\end{tabular}

2454-2261 ${ }^{\circledR}$ Copyright 2019. The Author. This is an open-access article under the CC BY-SA license (https://creativecommons.org/licenses/by-sa/4.0/) All rights reserved.

\footnotetext{
Author correspondence:

Tri Budiyanto,

Lecturer of Industrial Engineering Department, Faculty of Industrial Technology,

Ahmad Dahlan University, Yogyakarta.

Email address: tri.budiyanto@ie.uad.ac.id
}

\section{Introduction}

The growth of small and medium-sized industry (Indonesian: IKM) in Indonesia has a promising growth. It is shown by the increasing number of IKM which reaches more than 4 million in 2017 and followed by the growth of the workforce. The small and medium-sized industry has a large workforce capacity, has a characteristic of labor-

\footnotetext{
${ }^{a}$ Faculty of Industrial Technology, Ahmad Dahlan University, Yogyakarta

${ }^{\mathrm{b}}$ Faculty nembers, Post Graduate Study, Medical School Udayana University, Denpasar, Bali, Indonesia

${ }^{c}$ Faculty nembers, Post Graduate Study, Medical School Udayana University, Denpasar, Bali, Indonesia

${ }^{\mathrm{d}}$ Faculty nembers, Post Graduate Study, Medical School Udayana University, Denpasar, Bali, Indonesia
} 
intensive, and also able to sustain an economic downturn. In general, the small and medium-sized industry applies a simple technology with its labor intensive and does not depend on imported raw materials which make it an option because its endurance is proven in sustaining an economic crisis (Amri et al., 2015). One of the small and mediumsized industries which has a promising prospect and to date is still able to survive well is the metal casting small industry specifically aluminum casting. The aluminum product, which is used by many automotive components distributors, is also used by household industries with products such as wok, pan, bread molder, etc.

The molding process of household appliances made from aluminum in a small industry still uses work facility which does not pay attention to the anthropometry of the workers including the molding of the aluminum wok. During the wok molding process, which requires approximately 1.45 minutes for each wok, workers have to perform a bending work posture for a couple of times repetitively. The work facility such as wok molder is operated manually and some other supporting facilities such as the water container, the temporary place for the end product, the stamper of the folder which is made from wood, the brush, and the place for the diluted clay liquid is still placed on the irregular positions and do not suit the dimension of the workers' body.

A work tool which does not suit the user will cause an unnatural work posture and can cause fatigue, uncomfortable feeling, and reduce the work efficiency (Kroemer \& Grandjean, 2000), further, it will make the processing time longer and decrease the production output. The inappropriate or unnatural work posture is considered as one of the significant risk factors which cause musculoskeletal disorders (Kohnavard et al., 2018). The design of the equipment or machine which does not suit the body dimension of the user can cause a nonphysiological work posture, uncomfortable feeling, product quality decrease which is caused by work mistakes which in the end will result in the decrease of processing time speed.

The work activity of the workers in the work station of aluminum wok has not met the ergonomic principles. The operators work in a bending work posture using hand reach which surpasses their maximum reach range because the placement of the equipment and the material are far from the reach of the operators. The bending movement which is done for 6 times in one work cycle per unit is identified on some work postures such as lifting and putting back the molder cover to the molder, taking water using a brush to speed up the drying of the wok after the casting, placing and taking the stamping wood of the molder, and placing the end product on the temporary place. A physical work using a strong force is a classical task which triggers the growth of musculoskeletal disorders such as lifting and bringing, pushing, pulling, and manipulating a heavy object (Roman-Liu, 2013). The musculoskeletal disorders can be triggered by an awkward posture, a lifting activity, a strong movement, and a manual work on high speed (Ansari \& Sheikh, 2014).

The working posture in molding a wok is done repetitively for 7 work hours per day which can cause musculoskeletal disorders and fatigue of the workers. The main factors which cause musculoskeletal complaints are excessive muscle stretching, monotonous and repetitive activity, and the unnatural work posture (Dul \& Weerdmeester, 2008; Tarwaka, 2015). The awkward work posture has a higher risk which causes pain or injury on the musculoskeletal system which is known as musculoskeletal disorders. The injury risk on musculoskeletal can increase because of a work posture which is wrong, awkward, and unnatural or unusual (Bridger, 2003).

Problems related to work posture which can cause musculoskeletal disorders can be analyzed using RULA (Rapid Upper Limb Assessment) method. Posture, force or load, and muscles activity which are known to contribute toward the use of upper body parts (upper limb disorders) can be assessed using the RULA method (Corlett, 2005). This method provides the calculation in an activity which has a risk on upper body parts from the stomach to neck based on the level of complaint which is felt. The level of risk is shown by a high score and vice versa. RULA is developed as a method which can be applied to detect a work posture which has the potential of having a risk factor on upper body parts. RULA examines the exposure of an individual work toward risk factors related to an activity which deals with the upper extremity disorders (Bhandare et al., 2013).

In the wok molding activity, the workers work using a bending work posture which is done repetitively using upper body parts, therefore, the workers have a potential of being exposed to muscles injuries. This kind of problem can be analyzed using RULA method to measure the impact of an improvement of a work facility design toward workers complaint level by comparing the assessment score before and after the application of the improved work facility design.

Budiyanto, T., Adiputra, N., Sutjana, I. D. P., \& Tirtayasa, K. (2019). Application of RULA analysis on work posture improvement to reduce workers' fatigue and musculoskeletal complaints and to accelerate processing time of wok molding. International Research Journal of Engineering, IT \& Scientific Research, 5(4), 8-15. https://doi.org/10.21744/irjeis.v5n4.648 


\section{Materials and Methods}

The research was conducted experimentally by applying the treatment by subject design with samples of 12 wok molding workers. There were two treatments; molding wok using the former molder facility (P0), and molding wok using the new molder facility with an ergonomic approach improvement (PI). The analysis of work posture on P0 and P1 was done by applying the RULA method. The musculoskeletal complaints were measured using Nordic Body Map questionnaire and fatigue, in general, was measured based on the result of 30 items Self Rating Questionnaire Industrial Fatigue Research Committee from Japan Association of Industrial Health. The processing time was measured using a stopwatch for 2 work days both on treatment P0 and treatment P1, which then were compared and analyzed. The significant difference of the processed data results before and after the improvement of work facility through ergonomics approach was identified through statistical analysis using Paired Sample t-Test on a significance level of $5 \%$.

\section{Results and Discussions}

\subsection{Subjects' Characteristics}

All of the subjects were male with a total sample of 12 persons. The subjects' characteristics which were examined covered age, height, weight, body mass index (BMI) and working experience. The complete analysis result of the subjects' characteristics of the research can be seen in Table 1.

Table 1 Research Subjects' Characteristics Data Based on Age, Height, Weight, BMI, and Working Experience

\begin{tabular}{llllll}
\hline No. & Description & Minimum & Maximum & Mean & SD \\
\hline 1. & Age (years old) & 24 & 48 & 33.08 & 8.44 \\
2. & Height $(\mathrm{cm})$ & 155 & 67 & 162 & 3.77 \\
3. & Weight $(\mathrm{kg})$ & 44.8 & 63.3 & 54.68 & 7.85 \\
4. & Body Mass Index (kg/m2) & 17.5 & 25.9 & 20.83 & 3.06 \\
5. & Working Experience (years) & 2 & 17 & 9 & 5.78 \\
\hline
\end{tabular}

Based on Table 1, the age of the subjects was in the range of $24-48$ years old with a mean score of $33.08 \pm 8.44$ years old. It means that the subjects' age was in the productive category to work in the industry. Based on the data from the Ministry of Health Republic of Indonesia in 2016 (Kementrian Keseharan Republik Indonesia, 2016), both the range and the mean of the subjects' age are in accordance with the limit of productive working age which is between 15-64 years old. In general, workers who are in that range have a higher productivity level compared to those who are above 64 years old because of the difference in physical strength. The mean score of the body mass index was $20.83 \pm 3.06$ and in the range of $17.05-25.9$. The score of the body mass index of the workers was in the normal range which is $18.5 \leq \mathrm{BMI}<24.9$ (Kementrian Kesehatan Republik Indonesia, 2013). It shows that the body size of the subjects was not in the category of fat or thin. The subjects' working experience was in the range of $2-17$ years with a mean score of $9 \pm 5.78$ years. Based on the average length of working experience, it can be said that the subjects had a sufficient experience which resulted in the high skill mastery of molding wok.

\subsection{RULA Analysis}

The RULA assessment was done on the work posture of the wok molding workers on the activity of placing the wok on the temporary place before and after the improvement of work facility design. The detail of both work postures can be seen in Picture 1 and Picture 2. The analysis using the RULA method for the condition before and after the improvement of the work facility of wok molding is shown in Table 2. 

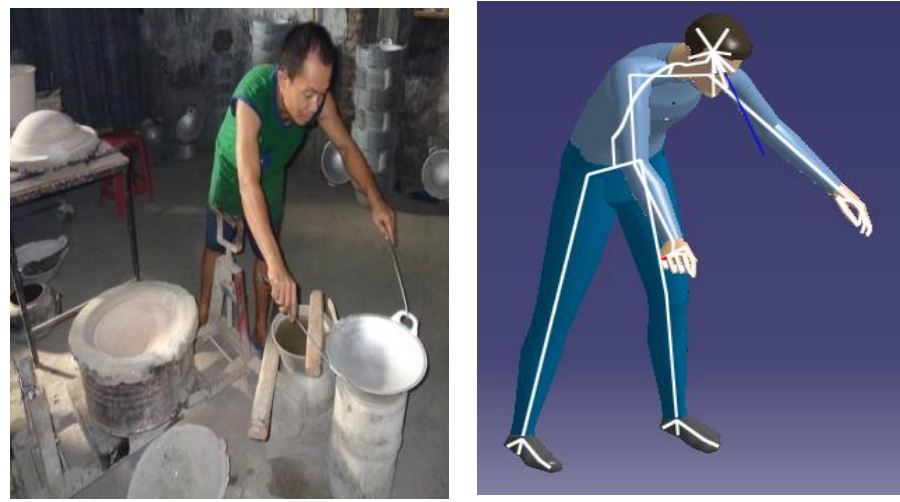

Picture 1. Work Posture of Placing the Wok onto the Temporary Place of the end Product Before the Treatment (P0)
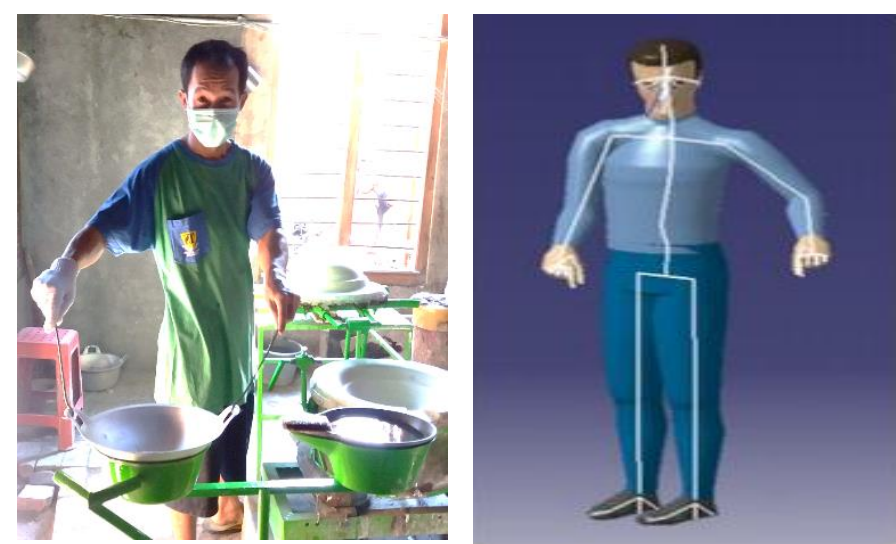

Picture 2. Work Posture of Placing the Wok onto the Temporary Place of the End Product After the Treatment (PI)

Table 2

RULA Analysis Result

\begin{tabular}{|c|c|c|c|c|c|}
\hline & \multicolumn{3}{|c|}{ Before the Treatment $(\mathrm{P} 0)$} & \multicolumn{2}{|c|}{ After the Treatment (PI) } \\
\hline & & Right Hand & Left Hand & & Left Hand \\
\hline Upper Arm & 4 & 3 & & 3 & 2 \\
\hline Forearm & 2 & 3 & & 3 & 2 \\
\hline Wrist & 2 & 4 & & 2 & 3 \\
\hline Wrist Twist & 1 & 1 & & 1 & 1 \\
\hline Posture A & 4 & 5 & & 4 & 3 \\
\hline Muscle & 1 & 1 & & 1 & 1 \\
\hline Force Load & 0 & 0 & & 0 & 0 \\
\hline Wrist and Arm & 5 & 6 & & 5 & 4 \\
\hline Neck & 4 & 4 & & 1 & 1 \\
\hline Trunk & 5 & 5 & & 2 & 1 \\
\hline Leg & 1 & 1 & & 1 & 1 \\
\hline Posture B & 7 & 7 & & 2 & 1 \\
\hline Neck, Trunk, and leg & 8 & 8 & & 3 & 2 \\
\hline Grand Score & 7 & 7 & & 4 & 3 \\
\hline
\end{tabular}

Budiyanto, T., Adiputra, N., Sutjana, I. D. P., \& Tirtayasa, K. (2019). Application of RULA analysis on work posture improvement to reduce workers' fatigue and musculoskeletal complaints and to accelerate processing time of wok molding. International Research Journal of Engineering, IT \& Scientific Research, 5(4), 8-15. https://doi.org/10.21744/irjeis.v5n4.648 
The result of RULA analysis in Table 2 for the work posture of placing the wok onto the temporary place before the treatment (P0) gave a score of 7 . A score of 7 means that the activity has a high-risk level and is recommended to have an improvement in work posture directly. The working posture of placing the wok onto the temporary place after the treatment through the ergonomic approach (PI) gave RULA score of 3, therefore there was a decrease from high risk to low risk.

A high RULA score means that a work posture can cause pain on workers body if it is done repetitively. A work posture with RULA score of 7 often causes pain on the certain body part and can cause high Musculoskeletal Disorders (MSD) (Djiono \& Noya, 2013). A work posture with RULA score of 3 is categorized into the low-risk activity which can be said as safe enough but a further examination is still needed to accelerate the processing time and increase productivity. RULA approach is suitable to detect the improvement of a work posture from the condition of high risk into the low risk or more natural work posture. The RULA method can be used to improve the work posture which is unnatural into a work posture which is more natural (Yusuf et al., 2016; Santosa \& Yusuf, 2017). The RULA analysis result recommends that the improved work facility of wok molding is more ergonomic or more natural and applicable even though there are still some improvements needed.

\subsection{Subjective Complaints}

The subjective complaints consist of fatigue in general and musculoskeletal complaints. The mean score of subjective complaints is served in Table 3 as follows.

Table 3

Mean Score Result of Subjective Complaints of the Wok Molding Workers Before and After the Work on Period 0 and Period I

\begin{tabular}{|c|c|c|c|c|c|c|c|c|}
\hline \multirow{2}{*}{ No } & \multirow{2}{*}{ Description } & \multicolumn{3}{|c|}{ Before the Improvement (P0) } & \multicolumn{3}{|c|}{ After the Improvement (PI) } & \multirow[b]{2}{*}{$\mathrm{p}$} \\
\hline & & Range & Mean & SD & Range & Mean & SD & \\
\hline 1 & before the & $30.5-33.5$ & 31.67 & 1.07 & $30.5-32.5$ & 31.29 & 0.72 & 0.202 \\
\hline 2 & Fatigue after the work & $5.5-54$ & 45.88 & 5.63 & $31.5-35$ & 33 & 1.22 & 0.001 \\
\hline 3 & Muscles complaint before th & $29.5-32$ & 31 & 0.83 & -32 & 30.67 & 1.54 & 0.354 \\
\hline 4 & Muscles complaint after the work & $66-71$ & 68.38 & 1.64 & -53.5 & 50.38 & 1.67 & 0.001 \\
\hline
\end{tabular}

Based on the calculation in Table 3 above, the mean score of fatigue in general and musculoskeletal complaints of the workers before the work on treatment P0 and PI was p > 0.05. It means that there was no significant difference, thus, each treatment of P0 and P1 did not give influence toward fatigue and musculoskeletal complaints to the wok molding workers before the work. The fatigue in general and musculoskeletal complaints after the work on treatment P0 and PI gave the value of $\mathrm{p}<0.05$. It means that there was a significant difference in the subjective complaints after the work on treatment P0 and P1. The mean score of fatigue in general after the work was 45.88 for P0 and 33 for PI. It means that there was a decrease of 12.88 or $28.07 \%$. The mean score of musculoskeletal complaints after the work was 68.38 for P0 and 50.38 for PI. It means that there was a decrease of 18 or $26.33 \%$.

The change of work posture from P0 into P1 gave an impact on the decrease of fatigue and musculoskeletal complaints level. Before the improvement (P0), the workers did the task of molding the wok using a bending work posture which was done fast and repetitively. This condition showed an unnatural work posture which was not physiologic and accelerated fatigue and musculoskeletal complaints. A work posture which is not physiologic in working which is done in a long duration will create a load in the musculoskeletal system and will give a negative impact toward health and will make a worker unable to use his/her skill optimally (Manuaba, 1992). A nonphysiologic work posture can consume greater energy and will cause fatigue and various musculoskeletal system disorders (Rusni et al., 2017). After the improvement (PI), the workers molded the wok using a quite straight work posture and did not do a repetitive bending movement anymore, therefore, the workers did their activity using a more natural work posture. The change of the work posture was influenced by the application of the improved work facility design of wok molding which was more ergonomic by using the worker's anthropometry data which was supported by the improvement of the work station environment which was better than before. 


\subsection{Processing Time}

The processing time was measured using stopwatch instruments. It was recorded based on a product unit per minute for Period 0 and Period I. The result is shown in Table 4 as follows.

Table 4

Processing Time Data on Period 0 and Period II

\begin{tabular}{llllllc}
\hline No & Period & Min & Max & Mean & SD & $\mathrm{p}$ \\
\hline 1 & Period 0 & 1.44 & 1.48 & 1.46 & 0.01 & \multirow{2}{*}{0.001} \\
2 & Period I & 1.21 & 1.24 & 1.23 & 0.008 & \\
\hline
\end{tabular}

The result of measuring and calculating the processing time before the improvement (P0) and after the improvement (PI) gave the value of $\mathrm{p}<0.05$. It means that there was a significant difference in the speed of processing time between treatment $\mathrm{P} 0$ and treatment $\mathrm{P} 1$. The mean score of processing time was $1.46 \pm 0.01$ minutes/unit for $\mathrm{P} 0$ and $1.23 \pm 0.008$ minutes/unit for PI. Thus, there was 0.23 minutes/unit or $18.7 \%$ increase in processing time speed. The improvement of production facility design by considering the ergonomic principles can contribute to improving the work posture into a more natural one and giving a real impact on the acceleration of processing time speed. The design of handle-cutter work facility using ergonomic concepts in aluminum smelting industry in Yogyakarta accelerates production time from 15.12 seconds/band into 11.01 seconds/band, which is faster 4.11 seconds/band or 27.18\% (Budiyanto \& Putra, 2016). The ergonomic intervention in improving workers' work posture into more natural one can also contribute to accelerating the processing time.

\section{Conclusion}

Based on the research result and discussion above, some conclusions can be described as follows:

a) Based on the RULA analysis, the former work posture before the improvement (P0) gave RULA score of 7 . This score means that the worker's activity in placing the wok onto the end-product temporary place had a high risk and it was recommended that an improvement of the work posture was needed immediately. The working posture after the improvement using the ergonomic approach (PI) gave RULA score of 3 which means that there was a decrease from high-risk work posture into low-risk work posture. A work posture with a score of 3 is considered as quite safe but still needs further examination.

b) The improvement of the work facility design of the wok molding had decreased the fatigue in general as big as 12.88 or $28.07 \%$ and musculoskeletal complaints as big as 18 or $26.33 \%$. It also accelerated the processing time for 0.23 minute/unit or $18.7 \%$.

Therefore it recommended for wok molding worker to use ergonomic work posture (P1).

\section{Conflict of interest statement and funding sources}

The authors declared that they have no competing interest.

Statement of authorship

The authors have a responsibility for the conception and design of the study. The authors have approved the final article.

\section{Acknowledgments}

The authors would like to thank the Editor of IRJEIS for their valuable time, support, and advice in completing the current study.

Budiyanto, T., Adiputra, N., Sutjana, I. D. P., \& Tirtayasa, K. (2019). Application of RULA analysis on work posture improvement to reduce workers' fatigue and musculoskeletal complaints and to accelerate processing time of wok molding. International Research Journal of Engineering, IT \& Scientific Research, 5(4), 8-15. https://doi.org/10.21744/irjeis.v5n4.648 


\section{References}

Amri, Y., Hamzah, A., \& Syahnur, S. (2013). Peran Usaha Industri Mikro dan Kecil Dalam Penyerapan Tenaga Kerja Di Provinsi Aceh. Jurnal Ilmu Ekonomi ISSN, 2302, 0172.

Ansari, N. A., \& Sheikh, M. J. (2014). Evaluation of work Posture by RULA and REBA: A Case Study. IOSR Journal of Mechanical and Civil Engineering, 11(4), 18-23.

Bhandare, A., Bahirat, P., Nagarkar, V., \& Bewoor, A. (2013). Postural analysis and quantification of fatigue by using RULA and REBA techniques. In International Journal of Mechanical and Production Engineering.

Bridger, C. J., \& Booth, R. K. (2003). The effects of biotelemetry transmitter presence and attachment procedures on fish physiology and behavior. Reviews in Fisheries Science, 11(1), 13-34. https://doi.org/10.1080/16226510390856510

Budianto, A., Pangabidin, R., Syai'in, M., Adhitya, R. Y., Subiyanto, L., Khumaidi, A., ... \& Pratomo, I. (2017, October). Analysis of artificial intelligence application using back propagation neural network and fuzzy logic controller on wall-following autonomous mobile robot. In 2017 International Symposium on Electronics and Smart Devices (ISESD) (pp. 62-66). IEEE. https://doi.org/10.1109/ISESD.2017.8253306

Corlett, E. N. (2005). Static muscle loading and the evaluation of posture. Evaluation of human work, 453-496.

Djiono, Y. K., \& Noya, S. (2013). Working Posture Analysis And Design Using Rula (Rapid Upper Limb Assessment) Method In Production Process At PT. Indana Paint.

Dul, J., \& Weerdmeester, B. (2003). Ergonomics for beginners: a quick reference guide. CRC press.

Kementrian Keseharan Republik Indonesia. 2016. Profil Kesehatan Indonesia Tahun 2016

Kementrian Kesehatan Republik Indonesia. 2013. Profil Kesehatan Indonesia 2013. http://www.depkes.go.id/resources/download/pusdatin/profil-kesehatan-indonesia/profil-kesehatanindonesia2013.pdf

Kohnavard B., Shegerd M., Mousavian A., (2018). Ergonomic Assessment of Body Working Postures among the Employees of a Car Services Workshop Using OWAS Technique. International Journal of Musculoskeletal Pain Prevention, 3(1), 19-22.

Kroemer, K. H. (1997). Fitting the Task to the Human. A textbook of occupational ergonomics, 56-57.

Manuaba, A. (1992). Pengaruh ergonomi terhadap produktivitas. Bunga Rampai Ergonomi, 11, 126-133.

Roman-Liu, D. (2013). External load and the reaction of the musculoskeletal system-A conceptual model of the interaction. International Journal of Industrial Ergonomics, 43(4), 356-362. https://doi.org/10.1016/j.ergon.2013.04.002

Rusni, N. W., \& Rusni, N. W. (2016). Workplace Stretching Exercise dan Pemberian Teh Manis Memperbaiki Respon Fisiologis dan Meningkatkan Produktivitas Penjahit di PT. Fussion Hawai (Doctoral dissertation, Universitas Udayana).

Santosa, I. G., \& Yusuf, M. (2017). The application of a dryer solar energy hybrid to decrease workload and increase dodol production in Bali. International Research Journal of Engineering, IT \& Scientific Research, 3(6), 99-106.

Tarwaka, B. (2014). Ergonomi Industri: Dasar-Dasar Ergonomi dan Implementasi di Tempat Kerja.

Yusuf, M., Adiputra, N., Sutjana, I. D. P., \& Tirtayasa, K. (2016). The improvement of work posture using rapid upper limb assessment: analysis to decrease subjective disorders of strawberry farmers in Bali. International Research Journal of Engineering, IT \& Scientific Research, 2(9), 1-8. 


\section{Biography of Authors}

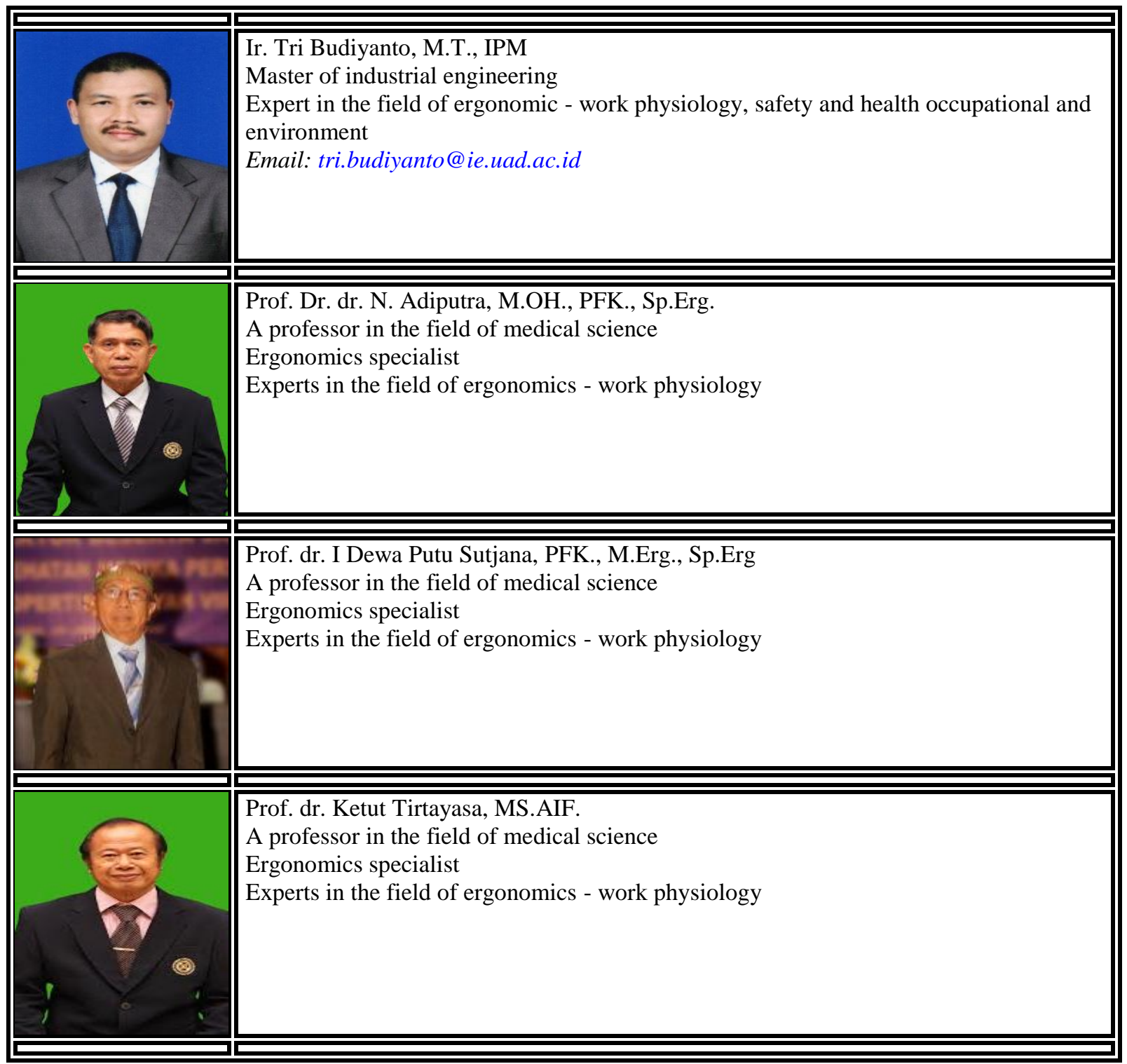

Budiyanto, T., Adiputra, N., Sutjana, I. D. P., \& Tirtayasa, K. (2019). Application of RULA analysis on work posture improvement to reduce workers' fatigue and musculoskeletal complaints and to accelerate processing time of wok molding. International Research Journal of Engineering, IT \& Scientific Research, 5(4), 8-15. https://doi.org/10.21744/irjeis.v5n4.648 